\title{
THE ARGON FIELD IN ARCADIA, THE SINKHOLE OF NESTANI VILLAGE, GOD POSEIDON AND THE SUBMARINE DINI SPRINGS IN THE ARGOLIC GULF (PELOPONNISOS, GREECE). A GEOMYTHOLOGICAL APPROACH OF THE POSEIDON'S BIRTH.
}

\author{
Mariolakos I.D. ${ }^{1}$, Mariolakos D.I. ${ }^{2^{*}}$ \\ ${ }^{1}$ Dr.rer.nat., Em. Prof. of Geology, Department of Dynamic Tectonic and Applied Geology, \\ School of Geology, National and Kapodistrian University of Athens, 157 74, Athens, \\ mariolakos@geol.uoa.gr \\ ${ }^{2}$ Geologist, MSc Environmentologist, Drs. Erasmus Univ., Rotterdam.
}

\section{ABSTRACT}

The Argon Field $(=\pi \varepsilon \delta i o=$ pedion, in greek $)$ is a small plain in the north part of the much larger Tripolis plain of Central Peloponnisos (Greece). It extends west of Mountain Artemision, which is dedicated to Goddess Artemis (Diana), between Sagas village and that of Nestani, at the province of Mantinia. The whole area of Mantinia is well-known since the prehistoric times and, as it is reported by Pausanias, it is mentioned in Greek Mythology.

Pausanias (Arcadica, § 7-8) mentions - among others - the following

The word "argon" means "slow cultivation", so that "Argon field" means a field of slow cultivation because of occasional flooding during wintertime, caused by water coming from the surrounding mountains and the karstic springs flowing from the margins, consisting mainly of multifolded cretaceous limestones (Pindos geotectonic unit). The Argon field would have probably turned into a lake, if the water had not been drained through a ground rift. In this case, the rift is apparently the cave - sinkhole of Nestani, which is located at the lowest topographic point of the whole field. After a few days (based on modern tracing experiments) the water reappears from this sinkhole in a submarine system of karstic springs in the Argolic gulf, that in ancient times were known as Dini, located near Kiveri village. The modern name of the springs is Mikros Anavalos or Aghios Georgios Springs.

The subsurface hydraulic communication between the Nestani Sinkhole and Dini springs was known to ancient greeks.

According to Greek Mythology when Goddess Rhea, one of the mythical Titans, gave birth to the Greek god Poseidon, she left him near a sheepfold next to a spring, which is known since then as Arna Spring (sheep = apvi = arni, in greek). Rhea didn't present the baby, Poseidon, to his father, Cronus, who was another mythical Titan, as she was afraid of him. At that time, Cronus was the head of the Titans, but fearing for a revolt of his children, he was eating them straight after their birth. That is why Rhea told him that she hadn't given birth to a child, but to a colt (small horse) instead (horse $=$ imrTo $=$ hippos, in greek). In this way, Poseidon survived and became one of the most important legendary Gods of the greeks later.

A locality is known next to Dini submarine system of kastric springs at the Argolic Gulf, named Genesion or Genethlion (= birthplace), which is considered to be Poseidon's birthplace. Here, in this place, the ancient inhabitants of Argos used to sacrifice horses, whereas not far away from Nestani, at the small village of Milia, the ruins of a small temple dedicated to Hippios (Horsey) Poseidon have been excavated during the last decades.

Dimitris passed away (10/11/2003) just before the last serial of the paper after a road accident (16/10/2003), when he was just 31 years old. 
Poseidon is depicted in many pictures, statues, mosaics etc. In a mosaic, Poseidon comes out from the water on a chariot pulled by four horses.

A main question is how Poseidon arrived from a mountainous area to the Argolic Gulf. A geomythological interpretation is that a god such as Poseidon, who was responsible for whatever happened in the water (sea, lakes, ground water etc.) and the earth interior (crust, lithosphere), could not follow a mountainous path, for instance the path over mountain Artemision. On the contrary, for such a god it would be much easier to follow the subsurface water-way through the sinkhole of Nestani village, that is the pathway connected to a subterraneous water flow, which reappears to the surface from the bottom of the sea and in this case to the surface of the Argolic Gulf, through Dini spring.

In the case of this myth the hydrogeological conditions of the area are directly connected to the mythological action. This is one more evidence that Poseidon is not a God imported from another culture, but a native one.

\section{INTRODUCTION}

The Argon Field is a small basin extended just after the exit of the Artemision tunnel, towards Tripolis (Central Peloponnisos).

It is a small polje in the NE part of the biggest Arcadian Plateaus. The Arcadian plateau, which is a much larger basin, is surrounded by relatively high mountains with a mean altitude of about 650 $\mathrm{m}$. and consists of many smaller poljes.

The Argon Field from a hydrological point of view is a closed system, whereas from a hydrogeological point of view is an open one, as the surface and/or groundwater are drained through sinkholes of the margins, or those of the bottom.

The margins and the older palaeo-surface of the bottom consist of alpine limestones. Above the bottom, a relatively thick sequence of younger, post-alpine clastic sediments has been deposited.

Argon Field extends between two relatively high mountains, mt. Artemision in the East as well as Lyrkeion and a smaller one, $\mathrm{mt}$ Alision, in the North.

The watershed of Artemision is the border between the Prefecture of Argolis and the Prefecture of Arcadia.

Pausanias has written a lot about the Argon Field, Nestani, Mantineia etc. (Figure 1a). In free translation Pausanias indicates the following (Figure1b): "... Entering the region of Mantineia, after crossing Artemision mountain (today we cross Artemision through the homonymous tunnel of the national road Corinth-Tripolis) we are in the Argon Field, that is called in this way because it cannot be cultivated. The reasons are related to rainwater that drains the surrounding mountain slopes and floods the field, making it inappropriate for cultivation. If rainwater had not disappeared trough a ground rift, the Argon Field could have been transformed into a lake.

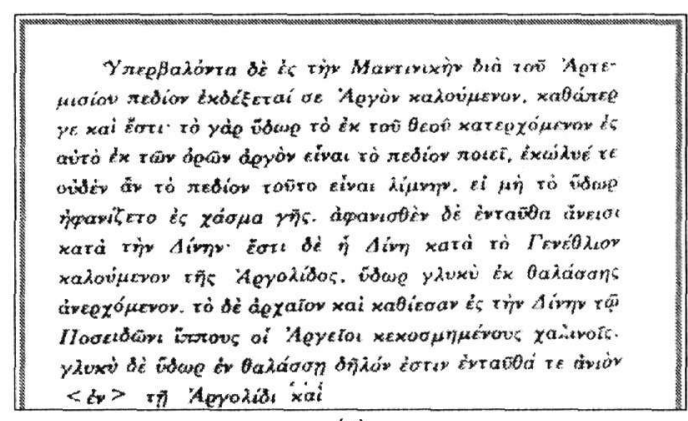

(a)
In free translation, Pausanias indicates the following:

Entering the region of Mantinia, after crossing Artemisio ftoday we cross Artemisio through the homonymous tunnel at the national road of Corinth - Tripoli) we are in the Argo Field, that is called in this way because it is not cultivated. The reasons for not being cultivated, are related to rain water that drains from the surrounding mountain slopes, floods the field making it inappropriate for cultivation. If rainwater had not disappeared through a ground rift, the Argo Field could have been a lake...."

(b)

Figure 1. Excerpt from Pausanias and a free translation (on the left). 
In Figure 2 we can see the Argon Field flooded, as a result of heavy rainfall during winter of 2003, whereas in Figure 3 a part of the plain is depicted with a snake-like furrow, where water flows towards the Nestani cave-sinkhole through it (see Figure 4). The "ground rift" of Pausanias is the sinkhole of Nestani, located at the margins of the field, just
below the cemetery of the village.

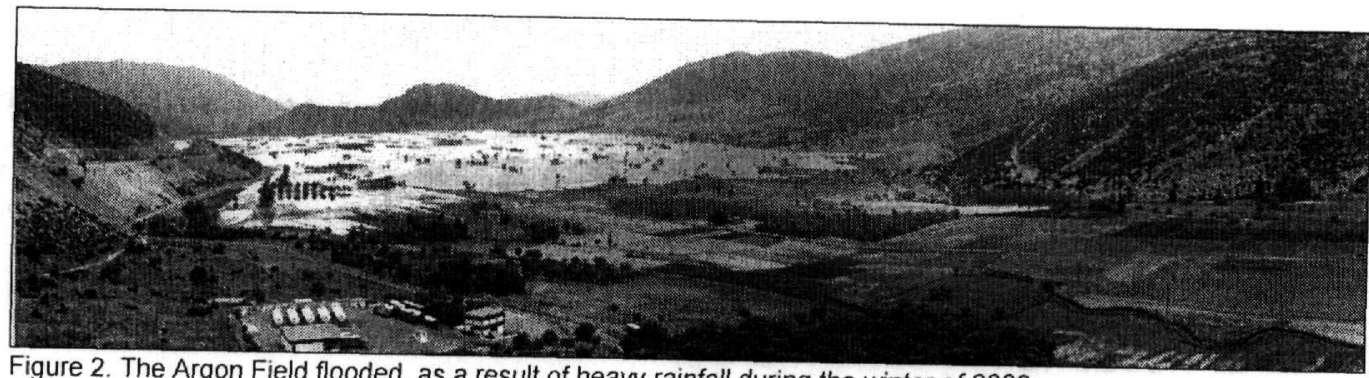

Figure 2. The Argon Field flooded, as a result of heavy rainfall during the winter of 2003.

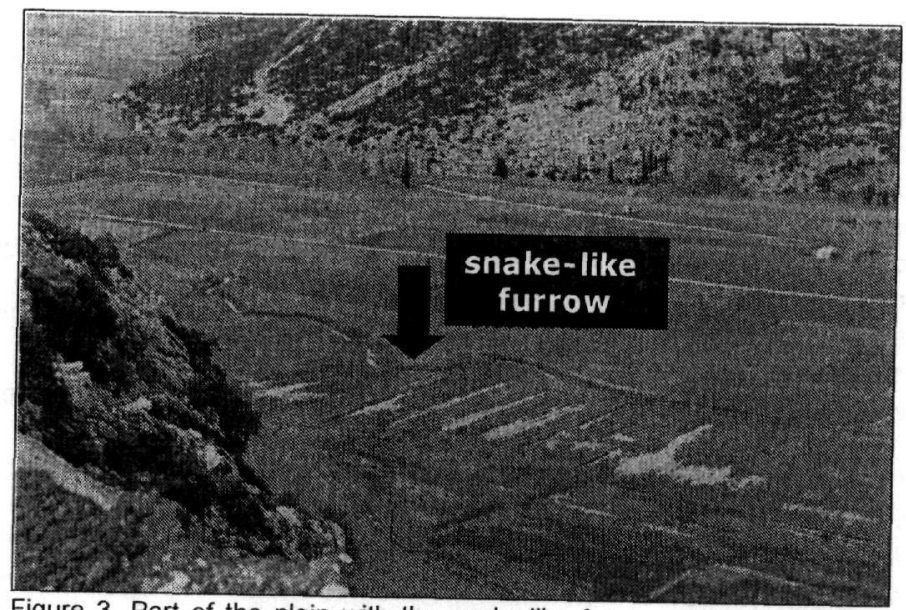
Figure 3. Part of the plain with the snake-like furrow, where water flows towards the Nestani cave-sinkhole
through it.

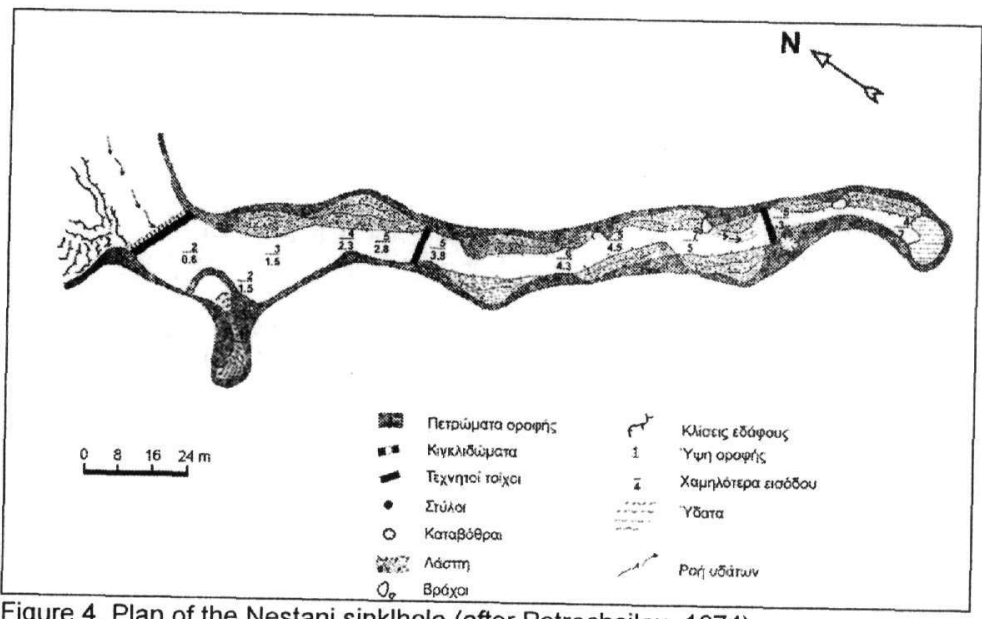

Figure 4. Plan of the Nestani sinklhole (after Petrocheilou, 1974) 


\section{THE WATER ROUTE}

Water from Nestani sinkhole, comes to Dini Spring.

Dini is the ancient name of a submarine group of krastic springs at the bottom of the Argolic Gulf, near Kiveri village. The actual name of the springs is that of "Micros Anavalos" and "Saint George Springs".

Next to the Dini springs, which are located some metres away from the coastline, two wellknown places are located. The first one is called Genesion, whereas the second one is known as Apovathmi.

The ancient Argeans used to sacrifice horses to God Poseidon at the place of Genesion, whereas, it is said that Danaos and his 50 daughters disembarked at Apovathmi, when they returned from Egypt. One of his daughters was Amymone that Poseidon met and fell in love with, when she was sent in search of water by her father, during a dry period, in order to provide Argos with drinking water. Due to his love for Amymone, Poseidon stroke the rock with his trident and water appeared at the area of Lerna.

The underground hydraulic connection, which was known to ancient Greeks, was verified with tracing experiments during the eighties. In Figure 6 the connection between the sinkhole of Arcadia Plateau and the three major karstic springs of Argolis is depicted schematically, based on tracing experiments.

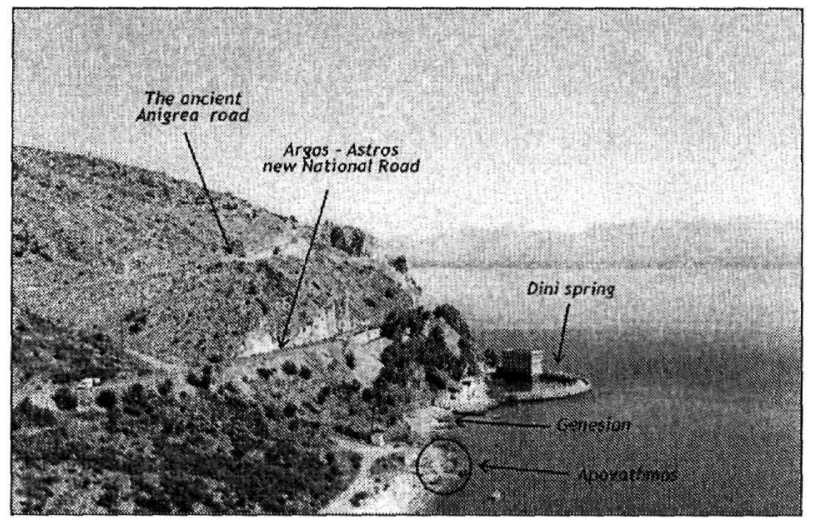

Figure 5. Dini Spring (Anavalos) and the location of Apovathmi and "Genesion", where Poseidon appeared.

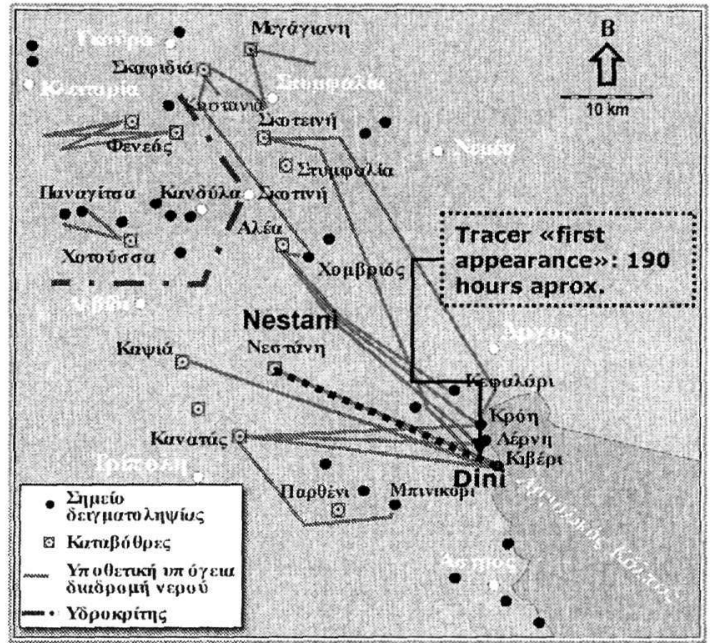

Figure 6. The connection between the sinkhole of Arcadia Plateau and the three major karstic springs of the Argolis is depicted schematically, based on tracing experiments (modified after Zojer et al., 1986). 


\section{THE GEOLOGY OF THE AREA}

Two main geotectonic units outcrop around the Argon Field, named Pindos and Tripolis units.

\subsection{Pindos Unit}

The thin-bedded Upper Cretaceous limestones are multifolded. On the small mountain Alision at the western margins of the Argon Field, a tectonic inversion is observed. In this case, the flysch sediments are overlain by the Cretaceous limestones of the Arcadian Nappe.

\subsection{Tripolis Unit}

It consists mainly of neritic carbonates. From a tectonic point of view, the geotectonic unit of Tripolis is overthrusted by the geotectonic unit of Pindos.

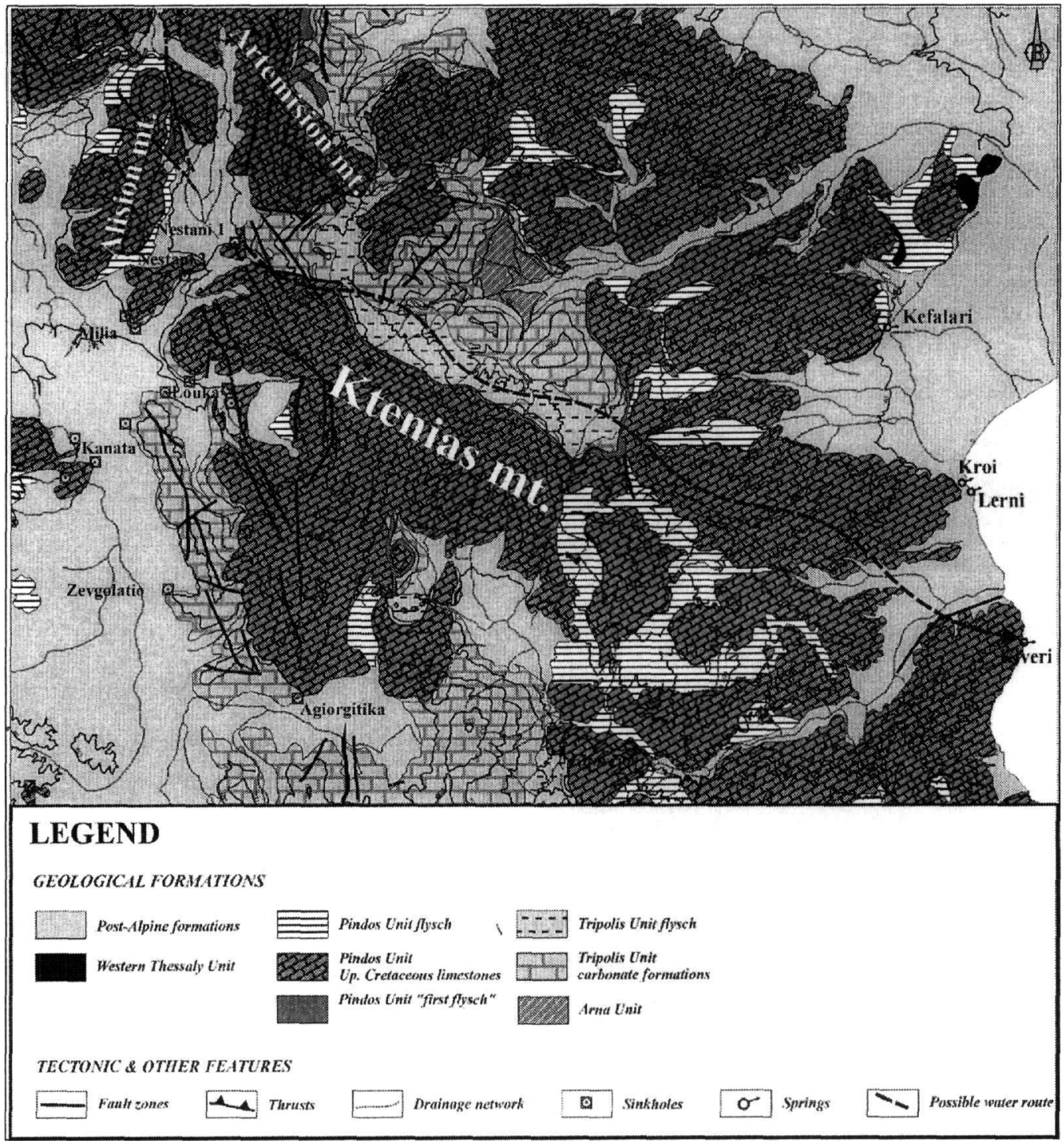

Figure 7. Geological map of the area. 


\section{MYTHOLOGY}

While Titan Rhea (the mother of all Great Gods) was pregnant, she found herself somewhere near Mantineia (=Ptolis = Nestani?), where she gave birth to God Poseidon. At that time, Cronus, Poseidon's father, was eating his children, because he was afraid they were going to overturn him. So Rhea left the baby near a spring, next to a sheep-pen, in order to protect him and told Kronos that she gave birth to a colt (baby-horse) instead. This spring was Arna ("arni" means sheep, in greek).

Milia village is located behind Arna spring., there is a temple dedicated to "Ippios (horsey) Poseidon" in Milia. Mantineia village is located further to the west.

\subsection{God Poseidon}

Poseidon is one of the six Great Gods of ancient Greeks. He was the God of the sea and all water, springs and the protector of flora.

According to the myth, he was able to provoke tempests or calm the sea by using his trident, which was his main characteristic. He created gulfs, straits and isthmuses (he was called "Isthmios" and "Porthmios"). By this trident he was also able to create springs and lakes (he was called "epilimnios", "limni" means lake in greek) and could change the water quality (he was called "phytalmios").

Poseidon was also the God of the interior of the Earth. He could move the Earth and cause earthquakes, that's why he was called "seisihthon", "gaioseistis" etc. (both of these words mean "he who moves the Earth").

\subsection{The Geomythological approach - The Proposal of Geomythological interpretation of Poseidon's birth}

Taking into account all the above mentioned and also that:

1. at Genesion, next to Dini, where the water from Argon Pedion ends up through the Nestani sinkhole, the ancient Argeans sacrificed horses to Poseidon,

2. that in Milia there is the temple of Ippios Poseidon and

3. that in a roman mosaic (Brado Museum, Tunis) Poseidon rises from the sea on a chariot pulled by 4 horses, then there can be no doubt that the emerging point of Poseidon has to be the greatest area of Dini and Genesion.

The Great Question: How can a God of springs, lakes and seas - a God - protector of water in general, and at the same time a God of the interior of the Earth to move from his birthplace, Nestani village, to his main action places, the Saronic gulf, the Aegean sea and the rest of the Hellenic area?

Is it possible that he moved over the mountains - mountain Artemision- as Artemis or Pan would do? No, it isn't.

Poseidon must have used the Nestani sinkhole to arrive to Dini, i.e. he used the route of the Argon Pedion waters.

\section{GENERAL CONCLUSIONS}

Some people may think that all the above-mentioned are a great story, but what do all these really mean? Is Greek Mythology nothing more than a tale?

Greek Mythology is not a product of imagination of the imaginative Greeks, but the encrypted physical and geological evolution of this area.

The hydrogeological conditions of the greatest area are directly connected to the actions of a God of the prehistoric Greeks. Poseidon could never be the creation of a different nation, adopted by the Greeks. He is an autochthonous God.

Poseidon may not be the first inhabitant of Mantineia Prefecture, but he is certainly the most famous of the prehistoric Mantineians and, why not, the Ptoleans (the inhabitants of Ptolis).

But, we have to note that not even one of today's inhabitants of Nestani is aware of its prehistory, with the exception of a few "initiated" ones. That is really a pity!! 


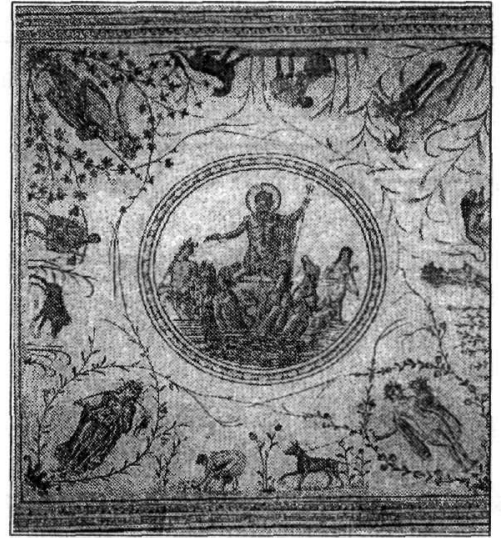

Figure 8. Roman mosaic depicting Poseidon rising from the sea on a chariot pulled by 4 horses (Brado Museum, Tunis).

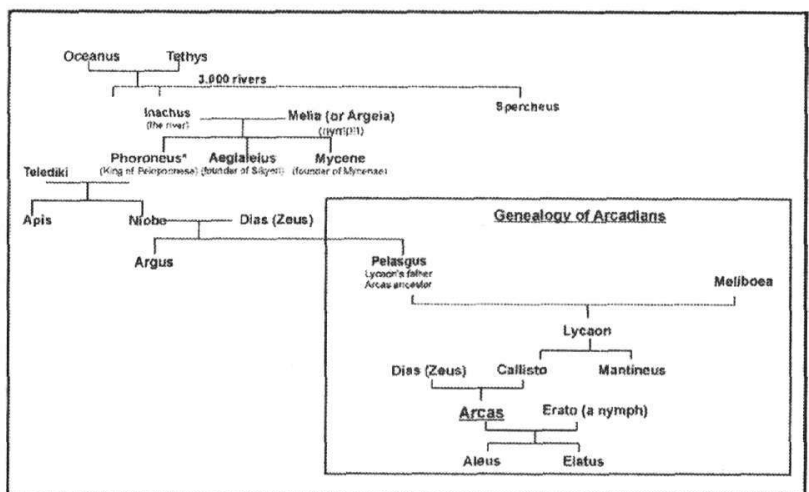

Figure 9. The genealogy of the ancient Arcadians.

\section{REFERENCES}

BERGER A., 1988. Milankowitch theory and climate-- Review of Geophysics, 26(4), 624-657.

CURTIUS E., 1892. Die Deichbauten der Minyer.- Sitzungsbericht der Berliner Akademie der Wissensch., Philosophisch-Historische Klasse, V. 55, pp. 1181-1193.

DAWSON A.G., 1992. Ice Age Earth: Late Quaternary Geology and Climate.- Routledge, 293 p, London.

DUFF D., 1993. Holme's principles of physical Geology - Chapman \& Hall, 791 p.

DIODORUS SICILUS, 1997. The Library of History, Book $5^{\text {th }}-$ The Greeks, Kaktos Ed. 405, Athens (in greek).

THEOCHARIS D., 1993. Neolithic Civilization. Educ. Inst. of the National Bank of Greece, 193 p. (in greek).

FAIRBRIDGE R.W., 1983. Isostasy and Eustasy.- In D.E. Smith and A.G.Dawson (eds): Shorelines and Isostasy, 3-28, Academic Press, London.

GUIOT J., PONS A., BEAULIEU L. \& REILLE M., 1989. A 140.000 year continental climate reconstruction from two European pollen records.- Nature, 338, 309-13.

JACOBSEN T., 1976. 17.000 Years of Greek Prehistory.- Scientific American, 234.

JINSUN JI., NICOLE PETIT-MAIRE \& ZHONGWEI YAN., 1993. The last 1000 Years climatic change in arid Asia and Africa.- Global and Planetary Change, 7, 203-210.

IMBRIE J. \& IMBRIE K.P, 1979. Ice Ages: solving the mystery.- Macmillan, 229 p., London.

ISAR A. S. \& BRUINS H.J., 1983. Special climatological conditions in the desserts of Sinai and the Negev during the latest Pleistocene.- Paleo 3, 43, 63-72, Elsevier Science Publishers, Amsterdam.

KAKRIDIS J., 1986. Greek Mythology. - Ekdotiki Athinon, v. 4 (in greek).

KNAUSS J., 1984. Die Wasserbauten der Minyer in der Kopais - Die aelteste Flussregulierung Europas (Kopais 1).- Wasserbau und Wasserwirtschaft, Nr. 50. Technische Universitaet Muenchen.

KNAUSS J., 1987. Die Melioration des Kopaisbeckens durch die Minyer im 2 Jt. v. Chr. - Wasserbau und Siedlungsbedingungen im Altertum (Kopais 2). - Wasserbau und Wasserwirtschaft, Nr. 57. Technische Universitaet Muenchen.

KNAUSS J., 1996. Argolische Studien: Alte Strassen - Alte Wasserbauten.- Wasserbau und Wasserwirtschaft, Nr. 77, Technische Universitaet Muenchen.

KRAFT, J. C., RAPP, G., SZEMLER, G.J., TZIAVOS, C., and KASE, E.W., 1987. The Pass at Thermopylae, Greece: Jour. of Field Archaeology, v. 14, 181-198.

LEHMANN H., 1937. Landeskunde der Ebene von Argos und ihrer Randgebiete (Argolis I).- Deutsches Archaeol. Inst., Athen.

MARIOLAKOS, I., 1975. Thoughts and viewpoints on certain problems of the geology and tectonics of Peloponnesus (Greece). Ann. Geol. Des Pays Helln., 27, 215-313 (in greek).

MARIOLAKOS I., FOUNTOULIS I. \& KRANIS H., 1997. Introduction to the Geology of Sterea Hellas, Hellenic Territory: Current geodynamic regime, Neoteconics of Corinthiakos Gulf, Delphi, Minyan Ancient Flood Prevention works. In: Boat and field trip guide of the 7th International Symposium Engineering Geology and the Environment IAEG (Editors: I. Mariolakos and Fountoulis, Geology and Tectonics, P. Marinos, G. Tsiambaos and M. Kakavas): Engineering Geology and Geotechnical Engineering. Hydrogeology), 60 p. 
MARIOLAKOS I., 1998. The Geomythological Geotope of Lerni Springs (Argolis, Greece) - Geologica Balcanica, 28, 3-4, 101-108.

MARIOLAKOS I., 1999. The Contribution of Geotopes to History and Environmental Sensitivity. 3_days Conference on the Conservation of Geological - Geomorphological Heritage, Syros, 12-14 July1996, IGME, 45-59 (in greek).

MARIOLAKOS I., 1999. Water, Man and Greek Civilization - Proc. of Symp. "The Water of Life", 18-21 November 1999, European Heritage Days, Athens (in print, in greek).

MARIOLOPOULOS I., 1938. The climate of Greece, 370 p., Athens

MILANKOWITCH M., 1941. Kanon der Erdbestrahlung und seine Anwendung auf dem Eiszeitenproblem.Royal Serbian Sciences, Spec. Publ. 132, Section of Mathematical and Natural Sciences, v. 33, 633 p., Belgrade.

MILOJCIC V., BOESSNECK J., JUNG D. \& SCHNEIDER H., 1965. Palaeolithikum um Larissa in Thessalien.B.A.M., I., Bonn.

MOERNER N.- A., 1971. Eustatic changes during the last 20.000 years and a method of separating the isostatic and eustatic factors in an uplifted area.- Palaeogeography, Palaeoclimatology, Palaeoecology, 19, 63-65.

MOERNER N.- A., 1976. Eustasy and geoid.- Journal of Geology, 88, 123-151.

OTA Y., 1987. Sea-level changes during the Holocene: the Northwest Pacific.- In R.Y.N. Devoy (Eds): Sea Surface Studies - A Global View, 348-374, Room Helm. Ltd, London.

PAEPE R., HATZIOTIS M.E., THOREZ J., OVERLOOP v. E. \& DEMAREE G.,1982. Climatic indexes on the basis of sedimentation parameters in geological and archaeological sections.-Palaeoclimatic Research and Models, Eds.: A. GHAZI, EEC, 129-138.

PAEPE R. and MARIOLAKOS I., 1984. Paleoclimatic reconstruction in Belgium and in Greece based on Quaternary lithostratigraphic sequences.- Proc. E.C. Climatology Programe Symposium, Sophia Antipolis, France, 2-5 October 1984.

PAUSANIAS. Arkadika. Ekdotiki Athinon.

PHILIPPSON A., 1892. Der Peloponnes.- Berlin.

PIRAZZOLI P.A., 1986. The early byzantine tectonic paroxysm. - Z. Geomorph. N.F., Suppl., 62, 31-49, Berlin.

PIRAZZOLI P.A., 1987. Sea-level changes in the Mediterranean.- In M.Y.TOOLEY and I. SHENNAN (eds). Sea Level Changes, 152-181, Basil Blackwell, Oxford.

POPE K. \& VAN ANDEL, Tj. H., 1984. Late Quaternary alluviation's and soil formation in the southern Argolid: its history, causes and archaeological implications.- Journal of Archaeological Science, 11, 281-306.

POUQUEVILLE F.-C.-H.-L.-, 1820. Voyage dans la Grèce.- Peloponnes. (Greek translation N. Molfeta), 478 p., Athens, 1997

RANKE-GRAVES R. von, 1955. Griechische Mythologie. Quellen und Deutung, Rowolts Deutsche Enzyclopadie, 2, 80 - 116.

RAPP G. \& GIFFORD J.A., 1982. Troy. The Archaeological Geology.- Supplementary Monograph 4, University of Cincinnati, Princeton University Press.

ROBERTS N., 1989. The Holocene: An Environmental History.- Basil Blackwell, 227 p., Oxford.

SCHNEIDER H., 1968. Zur quartargeologischen Etwicklungsgeschichte Thessaliens (Griechenland), Beitr.Ur-u. Fruhgesch. Archaol. d. Mittelmerr. - Kulturraumes (BAM), 6,. Bonn.

SCHWARZBACH M., 1974. Das Klima der Vorzeit: Eine Einfuhrung in die Palaoklimatologie.- Ferd. Enke Verlag, 380 p., Stuttgart.

SPYROPOULOS TH., 1973. An Introduction to the Study of the Kopais Area.- AAA, 6, p.201 (in greek).

SPYROPOULOS P., 1997.. A Chronicle of the Earthquakes of Greece from the Antiquity until Today - Dodoni Ed. 453 p. (in greek)

THIEDE J., 1974. A Glacial Mediterranean - Nature, 276, pp. 680-683.

VAN ANDEL T.H., 1998. Middle and upper Paleolithic environments and the calibration of $14 \mathrm{C}$ dates beyond 10.000 BP.- ANTIQUITY, 72, 26-33.

VITA-FINZI C., 1969. The Mediterranean Valleys.- Cambridge University Press.

ZANGGER E., 1991. Prehistoric Coastal Environments in Greece: The vanished Landscapes of Dimini Bay and Lake Lerna.- J. Field A., 18 (1991) 1-15.

ZANGGER E., 1993. The Geoarchaeology of the Argolida (Argolis II) - Deutsches Archaeol. Inst. Athen.

ZERVAS S., 1965. Hydrogeological study of the water resources of Argolis plain - Hellenic Ministry of Agriculture, Athens, (Report in greek). 